\title{
Farmers' consumption of an imported cereal and the cash/foodcrop decision
}

\section{An example from Senegal}

\author{
Henri P. Josserand
}

The effects of key agricultural policies on Senegalese farmers are analysed through a survey combining farming systems research methods, family budgets, dietary and anthropometric studies for the same rural households. Policies impact their food consumption through farm and non-farm incomes, prices of inputs, extension and research, and the prices of basic foods. Food consumption is closely related to family success in mixed cropping, but millet remains the basic rural food. Although rice has deeply penetrated rural markets, a malntenance of export earnings will require simultaneous gains in yields for both cash and traditional foodcrops.

Keywords: Food consumption; Farmers; Senegal

The author is Senior Research Associate at the Center for Research on Economic Development, University of Michigan, Ann Arbor, Ml 48109, USA.

This article is based on primary data collected for a report to the Nutrition Economics Group, United States Department of Agriculture, and the United States
In the West African context, the view is commonly held that imports of foodgrains and their sale at a low price through public channels are designed chiefly to provide urban populations with an 'affordable' basic foodstuff. Given the perceived need to continue earning foreign exchange by exporting cash crops, and current low productivity in West African foodcrop production, substantial grain imports are required to avoid severe shortages and/or a politically unacceptable rise in the market price of domestic cereals.

Senegal is a case in point. Table 1 shows the progression of net rice imports since the $1960 \mathrm{~s}$; by 1979 , net rice imports amounted to 352 thousand tonnes yearly, making up about $26 \%$ of total cereal consumption in Senegal (imported and domestic rice, millet, sorghum and maize, cf Table 2).

Urban consumption of rice imported into Senegal has not been subsidized in the recent past: the world price has been low relative to domestic production costs, and - contrary to the cases of, say, Mali or Niger - transportation costs have been acceptably low. Actually, not all transportation charges should be considered as net economic costs of rice imports because, in the absence of rice imports, millet/sorghum would have to be transported from rural to urban centres. In any case, rice imports effectively impose an upper limit on the market price of locally grown cereals. This has traditionally made the production and marketing of a substantial grain surplus less attractive to Senegalese farmers than some cash-foodcrop combination where the quantity of cereal grown is mostly determined by the family's own grain requirements (taking interannual grain stocks into account). ${ }^{3}$ The level of imports and market price of rice are thus commonly - and rightly associated with both basic urban consumption and domestic cereal output. For instance, rice is by assumption treated as a 'normal good' at the aggregate level, ie the demand for it is price elastic, with a negative 
Table 1. Net rice imports, $1960-79$.

\begin{tabular}{ll}
\hline & '000 tonnes \\
$1960-64$, average & 119 \\
$1965-69$, average & 165 \\
$1970-74$, average & 177.5 \\
1975 & 101.8 \\
1976 & 235 \\
1977 & 276.8 \\
1978 & 234 \\
1979 & 352
\end{tabular}

Sources: FRI, Stanford, 1979; BCEAO, 1982.
Agency for International Development, on the food consumption effects of agricultural policies in West Africa. ${ }^{1,2}$

${ }^{1}$ Edgar Ariza-Niño, Consumption Effects of Agricultural Policies, CRED, University of Michigan, Ann Arbor, Ml, 1982.

${ }^{2}$ Henri Josserand and Clark Ross, Consumption Effects of Agricultural Policies: Senegal Case Study, CRED, University of Michigan, Ann Arbor, MI, 1982.

${ }^{3}$ See, for example, Clark Ross in Market ing, Price Policy and Storage of Food Grains in the Sahel, CRED, University of Michigan, Ann Arbor, MI, 1977.

Note: aThis does not include wheat flour imports or food aid. coefficient: a price increase, other things being equal, is associated with a decrease in quantity demanded, and positively income elastic; ceteris paribus an overall rise in real income would lead to increased consumption.

However, the nutritional impact upon various groups of a general increase in food consumption has been shown to depend both on income distribution and commodity-specific consumption patterns among several income strata. ${ }^{4,5}$ Similarly, the potential impact of a change in the price of imported rice on export crop production and foreign exchange receipts is seldom explicitly considered. This article attempts to show that by investigating not merely urban but also rural rice consumption patterns, which may be fundamentally different, one adds a significant dimension to the food/cash crop dilemma of Senegalese agricultural policy.

\section{The survey}

This study stemmed from the increasing recognition of the need to consider food consumption and nutrition in the agricultural planning process to avoid harmful repercussions among populations already at risk. In this case, the emphasis was placed on the rural milieu, through a survey of three farming communities of the Senegalese Peanut Basin: a Serer community, Séssène, and two Wolof villages in the Diourbel Region, Layabé and Thienthie. The main objectives were to provide information on current food consumption patterns and nutritional status for these villages, and to assess the extent to which rural food consumption may be affected by the nation's agricultural policy. In this context, agricultural policy is most often expressed through official producer prices for major cash crops - in this case, peanuts - prices of seed, fertilizer and other inputs, access to credit (likely tied to the delivery of the previous two items) and extension. A simple conceptual chain connecting agricultural policy at one end with nutritional status at the other is shown in Figure 1: farmers' planting and cultivating decisions in response to policy affect farm income and the quantity of food grown for household consumption. Unsold foodcrops and food purchased with monetary income, agricultural and other, constitute the total stock of food available to the family. Finally, nutritional status can be inferred from food consumption, given the overall health status of the population.

Exploring the links between the various stages of Figure 1 called for a combination of elements from farming systems research, rural household budget surveys and nutritional studies applied simultaneously to the sample population. The latter consisted of 720 persons belonging to 72 households drawn by systematic random sampling, and covered the period from 15 May to 15 August 1981 (a three-month data collection limit being specified by the sponsoring agency, as part of the experiment). Data collection was thus designed to provide information on:

\begin{tabular}{lllll}
\hline \multicolumn{4}{l}{ Table 2. Total cereal supply, 1979" ('000 tonnes) } & \\
\hline Imported rice & Domestlc rice & Millet/sorghum & Malze & Total \\
352 & 140 & 803 & 47 & 1342 \\
$(26 \%)$ & $(10.3 \%)$ & $(59 \%)$ & $(3.5 \%)$ & $(100 \%)$ \\
\hline
\end{tabular}




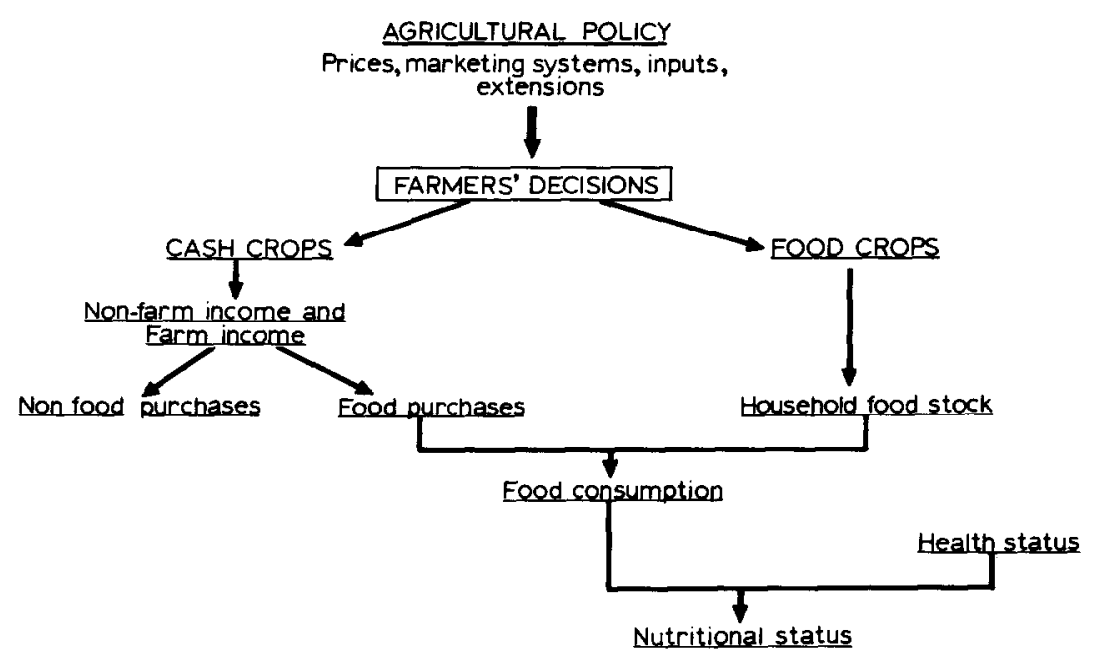

Figure 1. Conceptual chain linking agricultural policy with nutritional status.
${ }^{4}$ Per Pinstrup-Andersen and Elizabeth Caicedo, 'The potential impact of changes in income distribution on food demand and human nutrition', American Journal of Agricultural Economics, Vol 60, No 3, Aug 1978.

${ }^{5}$ Per Pinstrup-Andersen, Norha Ruiz de Londoño and Edward Hoover, 'The impact of increasing food supply on human nutrition: implications for commodity priorities in agricultural research and policy', American Journal of Agricultural Economics, Vol 58, No 2, May 1976

${ }^{6}$ On this widely documented phenomenon see, for example. Paul Pélissier, Les Paysans du Sénégal, Saint-Yrieux, Imp. Fabrèque, 1966, and Ref 7.

${ }^{7}$ André Lericollais, 'Sob, Etude Géographique d'un Terroir Serer', in Atlas des Structures Agraires au Sud du Sahara, ORSTOM, Paris, 1972.
General demographics.

Agricultural production:

- area of all fields cultivated by surveyed households;

- input and output data, per field, crop and household;

- marketing of farm produce and income.

- Nutrition:

- observed food intake for three consecutive days per household, converted to caloric and protein equivalent;

- weekly food purchases, per household;

- anthropometric measurements of the surveyed population: sex, age, weight and height.

- Income: total household income consisted of farm income, ie the market value of total grain production minus grain sales, plus farm receipts from sales of grain, peanuts and livestock, to which non-farm income - seasonally adjusted - was added.

\section{Results of the study}

The surveyed villages are in the same general area and face highly similar climatic conditions. Although all families followed the same strategy of allocating land in near-equal proportions to peanuts and millet, productivity (and thus income) within each village and from one community to the next varied greatly. Layabé families, for example, produced proportionately much more than their Thienthie neighbours, partly because of access to better soils, but also through the use of labour-extending technologies (farm equipment), allowing them to cultivate more land per comparable household (5.75 ha $v 2.6$ ha). The most successful village, Séssène, with soils quite similar to those of Layabé, achieved both higher yields and superior overall output by applying large quantities of cattle manure to their less extensive acreage (4.5 ha per household). Since other inputs per hectare did not significantly vary from those used in Layabé, we believe that most of the productivity difference stems directly from the careful integration of cattle raising into Serer farming practices. ${ }^{6,7}$ A comparison of total output of millet - the basic foodstuff - per village is quite telling: in the fall of 1980, the millet harvests for Layabé, Séssène and Thienthie were 49,68 and 10 tonnes, respectively. 
Notes: ${ }^{a} \$ 1=250$ CFA; ${ }^{b}$ Chickens, sheep and goats; 'Seasonally adjusted, earned in the village.

\begin{tabular}{|c|c|c|c|}
\hline Peanuts & $\begin{array}{c}\text { Layabé } \\
990\end{array}$ & $\begin{array}{c}\text { Séssène } \\
1827\end{array}$ & $\begin{array}{l}\text { Thienthie } \\
112\end{array}$ \\
\hline Millet & 509 & 128 & - \\
\hline Small livestock ${ }^{b}$ & 1041 & 994 & 2464 \\
\hline Cattle & & 7908 & 324 \\
\hline Horses & 320 & - & 828 \\
\hline Total farm income (cash) & 2860 & 10857 & 3728 \\
\hline Comparative index & 26.3 & 100 & 34.3 \\
\hline Non-farm income $\theta^{\circ}$ & y 688 & 3108 & $1 / 51$ \\
\hline Grand total & 12548 & 13965 & 5479 \\
\hline Overall comparative index & 90 & 100 & 39.2 \\
\hline
\end{tabular}

The level and pattern of agricultural sales and non-farm income throughout the year is also most revealing. Table 3 summarizes the various sources of income for each community over the 1980-81 period. Several points are particularly noteworthy:

- The very low level of millet production in Thienthie did not allow for any marketing of this basic food, as one might expect. Note, however, that millet sales were quite low in the most productive village, Séssène. People there had no need to sell a basic foodgrain when they were deriving significant money income from cattle sales.

- In Thienthie, people attempted to make up the cereal deficit through food purchases financed by the sale of small stock and horses. In this particular context, the level of small stock and horse sales at Thienthe clearly indicates not only maximum off-take, but serious destocking as well.

- Finally, we note that the highest non-farm income at Layabé (which did not include remittances) is thought to be consistent with this community's greater access to, and use of, labour-extending technology.

We may now see how this basic picture of agricultural production and income fits in with levels and patterns of family-grown or purchased foods. In a global sense, the most important food items for the three-monthly survey period were, in decreasing order of total quantity consumed: millet, rice, peanuts, curdled milk, smoked fish, peanut oil, salt, sugar, cowpeas, onions, etc ( 23 other food items were found to be consumed in significant amounts). Table 4 shows a breakdown of food consumption per village for the six most important food items. Note that high millet consumption in Séssène is consistent with very low rice intake (and thus oil, since they are complementary in food preparation). Séssène's milk consumption also stands out, next to that of two communities with little or no cattle. The amount of rice eaten in Thienthie is relatively very high, a point discussed in greater detail below.

As one would expect, the pattern of food purchases was closely associated with both food production and consumption. Table 5 shows

Table 4. Total consumption of major food items, by village, 15 May-15 August $1981(\mathrm{~kg})$.

\begin{tabular}{lccc}
\hline & Layabd & Sessene & Thienthie \\
Millet & 220 & 435 & 101 \\
Rice & 67 & 8 & 45 \\
Peanuts & 33 & 34 & 24 \\
Curdled milk & 6 & 33.5 & 3.3 \\
Oil & 15 & 1 & 9.2 \\
Smoked fish & 14 & 3.9 & 7.5 \\
\hline
\end{tabular}


Table 5. Average household expenditures on foodstuffs, by villege (US \$), and as proportion of money income.

\begin{tabular}{llll}
\hline & Layabé & Sessane & Thienthie \\
Average expenditures per household & 18.6 & 10.2 & 22.1 \\
As \% of money income & $14 \%$ & $7 \%$ & $43 \%$ \\
\hline
\end{tabular}

the average amounts spent by households on food purchases, by village, for the survey period, and a corresponding estimate for the proportion of yearly money income allocated to food items: absolute and relative expenditures on food items were inversely related to agricultural production and overall income (because of the importance of familygrown food in the measure of income). Conversely, the total quantity of food ingested by members of the surveyed population was positively correlated to income, and this is true whether one considered three income strata drawn from the entire sample, or across the three villages.

Due to the importance of peanuts in the diet, especially since the survey period covered shelling time, no protein deficiency was observed at any income level. This was not so in the case of caloric intake: virtually all the sampled households showed a caloric deficiency ranging from slight to quite severe. Table 6 outlines the distributional analysis of caloric intake by village, at the $90 \%$ confidence level. For example, one-half of the Thienthie population consumed less than the equivalent of $1821 \mathrm{kcal}$ per adult male daily. On the other hand, in Séssène, three-quarters of the surveyed population consumed more than the equivalent of $2302 \mathrm{kcal}$ per adult male daily.

Although the income-food intake correlation was clearly revealed throughout, it is interesting to note that a comparison between houschold income and anthropomctric mcasurements on children up to six years of age failed to highlight any significant relationship.

\section{The rice/millet issue and its policy implications}

The observed differences in rice consumption and purchases among the three villages are at the crux of the important rice/millet issue in rural Senegal. We saw that, in this case, the village with the highest total income bought and consumed the least amount of rice, while the poorest village consumed both the lowest total amount of grain (millet plus rice) and the highest proportion of rice in total grain. Intra-village differences in millet production and rice consumption were not so large as to invalidate the differences among villages. Before we look at these differences in detail, however, let us recall the major specific attributes of both grains.

Millet is the traditional food, and is more nourishing than rice.

Table 6. Distributional analysis of caloric intake, by village."

\begin{tabular}{llll}
\hline Village & $\begin{array}{l}\text { Probability } \\
\text { Layabe }\end{array}$ & $\begin{array}{l}\text { Quantile } \\
\text { (cal/person/day) }\end{array}$ & $\begin{array}{l}\text { Confidence interval } \\
1886-2428\end{array}$ \\
Séssène & 0.25 & 2110 & $1983-2541$ \\
Thienthie & 0.25 & 2302 & $1066-1736$ \\
Layabé & 0.25 & 1408 & $2230-2870$ \\
Séssène & 0.50 & 2521 & $2374-2748$ \\
Thienthie & 0.50 & 2588 & $1656-2180$ \\
Layabé & 0.50 & 1821 & $2712-3716$ \\
Sessène & 0.75 & 3022 & $2638-3269$ \\
Thienthie & 0.75 & 2780 & $1989-2922$ \\
\hline
\end{tabular}


Although it stores very well on the whole or split panicle, it does not keep so well in grain form, and does not keep at all once it has been ground. This requires that each day's supply be pounded or otherwise processed.

Rice, on the contrary, is not grown in the area, and is less nourishing, but it keeps well in grain form and does not require long and tiring processing before it is cooked. It also provides variety in the diet. However, depending on the season, rice is two to three times as expensive as millet, and its cost is further augmented by the large quantity of oil called for in the usual preparation. Finally, we note that rather small quantities of millet were found on rural markets, while rice was readily available.

Table 7 summarizes grain production, sales and consumption data for the three villages. The households surveyed in Séssène produced more millet than they would normally need in a year ( $28 \%$ more than a year's supply, assuming $200 \mathrm{~kg}$ per person annually). Very little of it was sold, at least until mid-August; since Séssène families already had the highest total income, they had little need to sell millet. Over the duration of the survey, virtually no rice was either bought or consumed.

In Layabé, the millet harvested by 24 families, adding up to 235 persons, amounted to 49 tonnes. The amount sold reached about 4.24 tonnes, or nearly $9 \%$ of the total harvested, leaving an average of $191 \mathrm{~kg}$ per person for home consumption. We hypothesize that people in Layabé did not sell any more millet because other sources of income especially non-farm income, highest of all three villages - allowed them to conserve the main food staple. Per capita rice consumption was highest in Layabè, although it was still less than one-third of millet intake.

The 217 persons comprising the families surveyed in Thienthie harvested only 10 tonnes of millet, barely enough to provide for one-third of a year's needs. They tried to make up part of this shortfall through destocking and dissaving (in no way can the sale of 10 horses by 24 families in 1 year be regarded as typical). Non-farm income did not improve the situation very much; it was the lowest of all three villages in absolute terms. As a consequence, total grain consumption was lowest in Thienthie - half of what it was in Layabé, and about one-third of Séssène's level. Considering that rice cost over twice as much as millet, one would expect that Thienthie's grain deficit would have been made up almost entirely through millet purchases, and yet $45 \%$ of all grain consumed in Thienthie was rice. These families probably wished to purchase more millet than they did, but could not, and therefore shifted to readily available (though much more expensive) rice. Two explana-

Table 7. Milletrice summary statistics, by village.

\begin{tabular}{|c|c|c|c|}
\hline $\begin{array}{l}\text { Millet harvest (autumn 1980) } \\
\text { Millet sales (up to survey) } \\
\text { Sales as \% of production } \\
15 \text { May-15 August } 1981 \\
\text { Total millet consumption, per household } \\
\text { Total rice consumption, per household } \\
\text { Total grain consumption, per household }\end{array}$ & $\begin{array}{l}\text { Layabs } \\
\text { (24 households) } \\
49 \text { tonnes } \\
4240 \mathrm{~kg} \\
8.6 \% \\
220 \mathrm{~kg} \\
67 \mathrm{~kg} \\
287 \mathrm{~kg}\end{array}$ & $\begin{array}{l}\text { Seseene } \\
\text { (24 households) } \\
68 \text { tonnes } \\
1063 \mathrm{~kg} \\
1.5 \% \\
435 \mathrm{~kg} \\
8 \mathrm{~kg} \\
461 \mathrm{~kg}\end{array}$ & $\begin{array}{l}\text { Thlenthie } \\
\text { (24 households) } \\
10 \text { tonnes } \\
0 \\
0 \\
101 \mathrm{~kg}^{\mathrm{a}} \\
45 \mathrm{~kg} \\
146 \mathrm{~kg}\end{array}$ \\
\hline $\begin{array}{l}\text { Average consumption per capita/day } \\
\text { Millet } \\
\text { Rice } \\
\text { Total grain }\end{array}$ & $\begin{array}{l}0.312 \mathrm{~kg} \\
0.095 \mathrm{~kg} \\
0.407 \mathrm{~kg}\end{array}$ & $\begin{array}{l}0.54 \mathrm{~kg} \\
\overline{0.55} \mathrm{~kg}\end{array}$ & $\begin{array}{l}0.155 \mathrm{~kg} \\
0.07 \mathrm{~kg} \\
0.224 \mathrm{~kg}\end{array}$ \\
\hline
\end{tabular}


tions appear as most likely: (a) Thienthie's own millet production did not allow for a marketable surplus, even by the most successful households; (b) after a series of rather bad years, even more productive villages were not keen on large millet sales. They could generate sufficient income through many other activities, eg peanuts, but also small and large ruminants, poultry and non-farm employment.

An overview of grain consumption as a function of income is depicted in Figure 2, and the three regression equations are presented below. At the lowest income levels, rice made up a very high proportion of total grain consumption, but since the rate of increase in millet consumption did not level off at the higher income levels observed, the proportion of rice in total grain fell consistently as income rose. This is representative of a situation where rice is a ready substitute for millet, and where both grains are still very much considered as essential goods for the levels of incomes observed.

Millet consumption/capita $=63.25+0.0064$ income/capita

$$
\text { (in } \mathrm{kg} / \mathrm{yr}) \quad(3.5) \quad(8.16)
$$

$R^{2}=0.6428, F=66.58 ; t$-values are in parentheses

Mean income elasticity of millet consumption $=0.594$

$$
\begin{aligned}
& \text { Rice consumption/capita } \\
& \text { (in kg/yr) }
\end{aligned}=\begin{gathered}
37.5+(7.55) \\
(4.00091 \text { income/capita } \\
R^{2}=0.3254, F=17.8
\end{gathered}
$$

Mean income elasticity of rice consumption $=0.26$

Total grain consumption/capita $=100.76+0.0073$ income $/$ capita

$R^{2}=0.6844, F=80.25$

$$
\text { (in kg/yr) (5.3) (8.96) }
$$

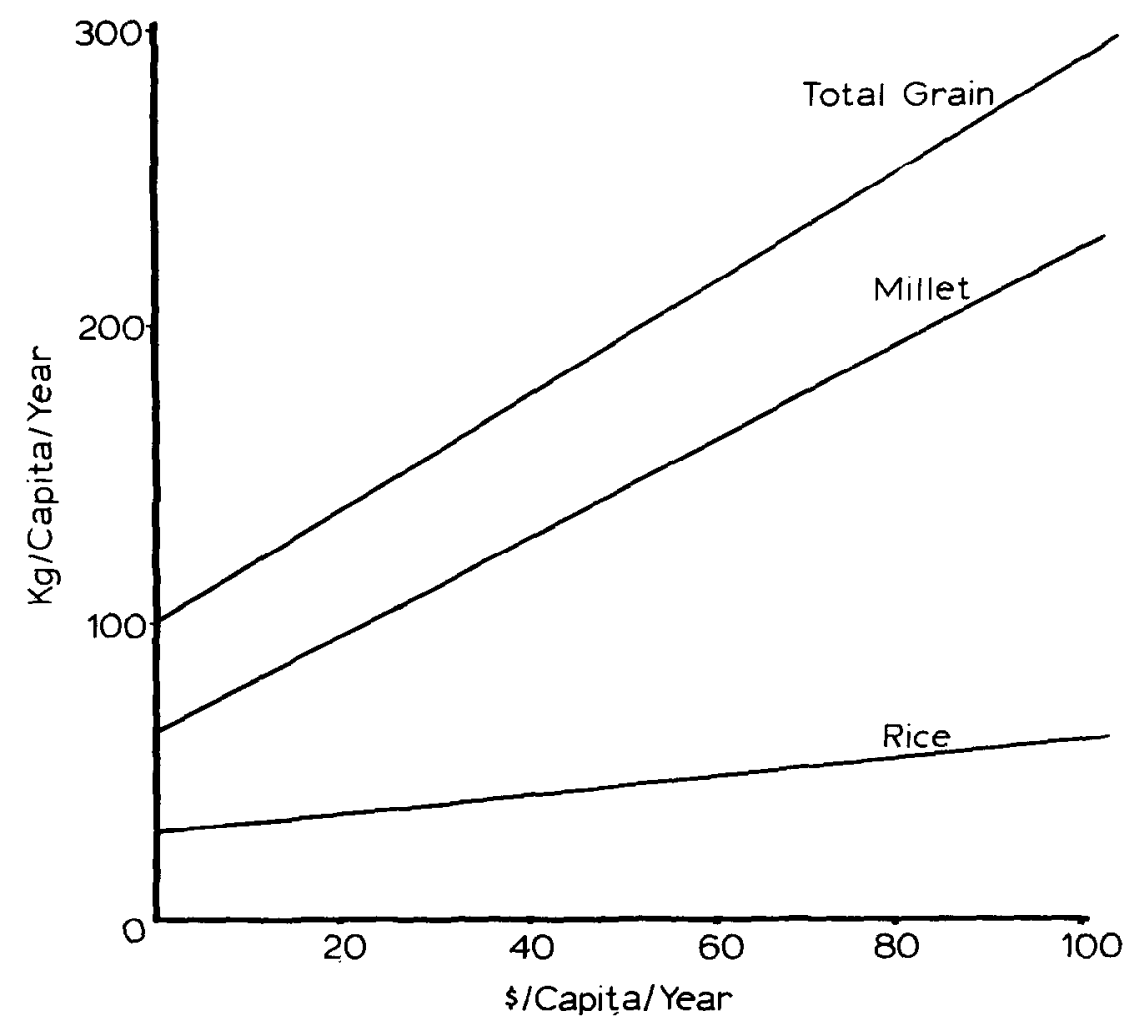

Figure 2. Millet, rice and total grain consumption, as a function of income. 
It is important to bear in mind that such overall relationships between cereal consumption and income mask the fundamental differences in consumption patterns revealed at a lower level of aggregation. The latter strongly suggest that, aside from being a typically urban staple, rice constitutes an important complementary source of food for low-income rural families, because the quantity of millet other local producers are willing to sell may be quite limited (given the availability and price of rice). In siluations where farmers combine significant shares of food and cash crops, an increase in the price of rice would given the high uncertainty attached to West African rainfed agriculture - sharply raise the farmers' potential cost, or risk value, of not producing enough cereals for household consumption. This would quite likely lead to a reallocation of inputs from cash to foodcrops.

The maintenance of a relatively low price for imported grain must therefore appear, to Senegalese planners, to be not only a way to foster urban satisfaction and promote political stability, but also a necessary means to preserve, in the form of export earnings, the chief source of public funds. 